DATA STRUCTURE OF INBOUND AND OUTBOUND MATERIAL FOR PLANNING AND LOGISTIC STREAMLINING IN COMPANIES

Peter Ignácz

\title{
DATA STRUCTURE OF INBOUND AND OUTBOUND MATERIAL FOR PLANNING AND LOGISTIC STREAMLINING IN COMPANIES
}

\author{
Peter Ignácz \\ CEIT Pro, s.r.o., Univerzitná 8413/6, 01008 Žilina, Slovakia, peter.ignacz@ student.tuke.sk
}

Keywords: data, structure, material, PFEP, inventory, calculation

Abstract: An accessible and streamlined data structure is a prerequisite for the proper and efficient operation of all activities related to each department in each company. In the case of production and logistics, it also fulfills the support function for planning changes or optimizing the current state in the light of easily and rapidly available data on materials found in the company. Such structured data is also referred to in the foreign literature by the abbreviation PFEP, which is the name of the Plan for each part, and in translation into Slovak, a plan for each part.

\section{Introduction}

The article was created on the basis of a case study from practice. The topicality of the article is also illustrated by the situation in the industry where there is a demand for ever greater energy savings and thus a saving of money while preserving the same price of products. It is precisely for this demand that the number of competing companies offering products for the same purposes is growing. That's why the goal is to make all processes more efficient across the company. The way the data structure, its updating, availability and method of processing should be effective as well. Efficient data management in production and logistics is important because logistics is able to influence the part of the costs that are taken into account in product pricing and therefore directly influences the competitiveness of the company. Waste and no value adding activities in processes today are not only in production or logistics activities, it can also be seen from data and table sharing, availability, upgrading and data integration in one place for their availability in the shortest possible time.

\section{Data and methodology}

For possible optimization of supply, it is necessary to have complete information on the materials and parts for production used in the manufacture and assembly process (Figure 1). The flow of information in the logistics system is as important as the flow of material, information is considered to be the main source in the logistics system [1]. This is the structure of data with the "plan for each part" (PFEP shortcut) (Table 1). It is essential that information is divided into elementary parts, e.g. pack sizes on separate column length, width, height, so it's easy to filter individual information. It is a great help in planning new racks, warehouses and also in the calculation of the load of supply tuggers, forklifts, or when designing the workplace.

An important part is also the PFEP section of the supplier's data sheet, delivery times, distance and supplier availability. These data can later be used to reduce inventory in the production process. Inventories address the time gap between production and consumption, local mismatch between production and consumption, capacity mismatch between downstream production and transport systems [2].

This is possible based on filtering and ordering of suppliers according to the distance and time of delivery of the material. With local suppliers, it is possible to use the principle of increasing the frequency of supply and reducing the supply of material.

By integrating the supplier rating column into the PFEP table, it adds importance to this data when defining the feed-in strategy for certain processes and also defining the supplier frequency of supply. It is necessary to determine the maximum and minimum size of inventory in the process and in the company's warehouses. Suppliers can be divided into reliable, sufficiently reliable or unreliable on the basis of a point assessment that takes into account the reliability of supplies and the reliability of the quality. Based on these criteria, it is possible to determine which suppliers are allowed to reduce inventories in stock because they have proved reliable in the long-term monitoring and evaluation.

Information can be physically collected and verified directly in production, but an effective way is to request this data from its suppliers. Logistics and the supply chain relate to physical and information flows, and storage from raw materials to final distribution of the finished product [3]. Each supplier should know his product, so filling this table should be a matter of purchasing staff. To update this spreadsheet on a regular basis, it is necessary to instruct the responsible person or multiple persons to update the spreadsheet after each change. This is the only way to maintain the integrity and veracity of the data in the table. Essential is table flexibility, speed, ease of operation and data tagging, and PFEP table readability.

The PFEP table can be created:

- MS Excel or another spreadsheet editor,

- In database software. 
DATA STRUCTURE OF INBOUND AND OUTBOUND MATERIAL FOR PLANNING AND LOGISTIC STREAMLINING IN COMPANIES

Peter Ignácz

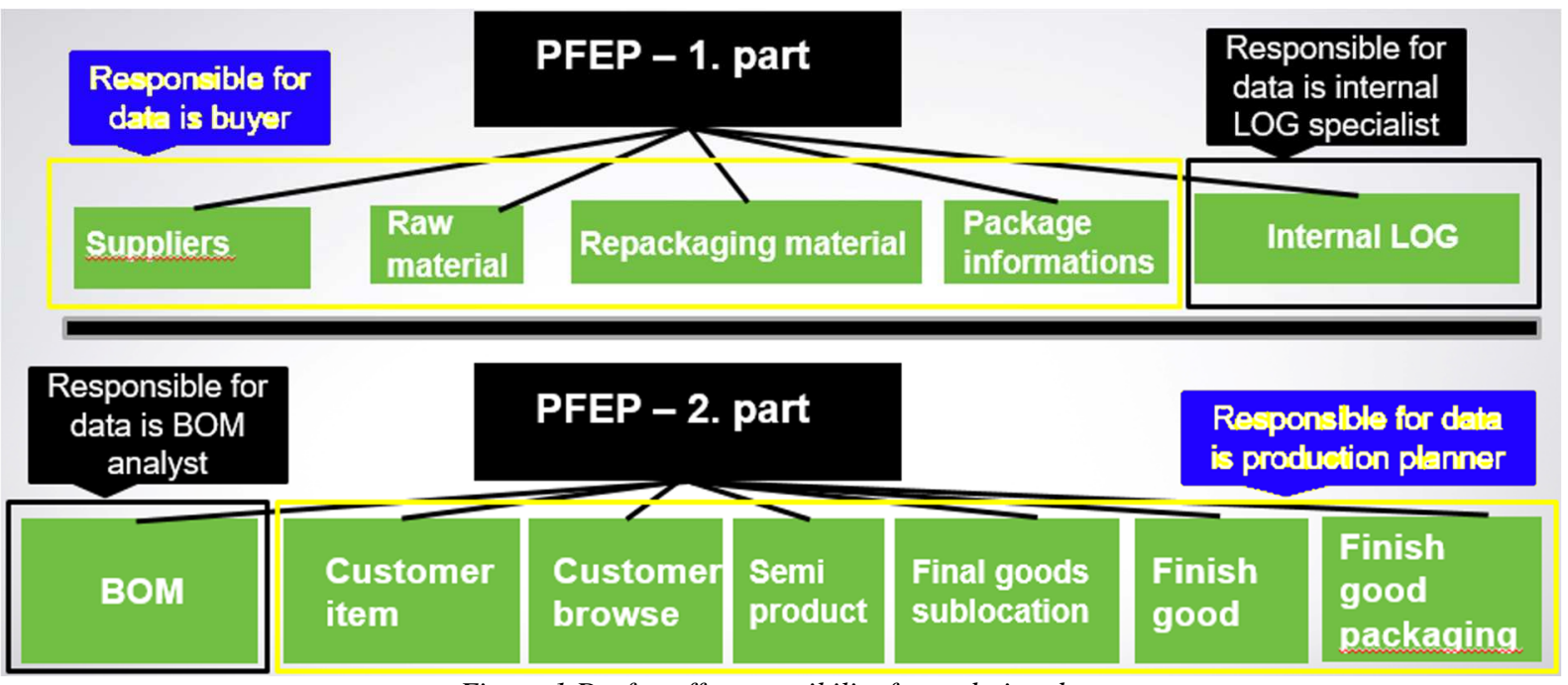

Figure 1 Draft staff responsibility for updating data

Table 1 Content of the basic data structure to create PFEP [4]

\begin{tabular}{|l|l|}
\hline Article number & The number used to identify the material internally \\
\hline Article description & Name of the material (e.g. frame, bolt, nut) \\
\hline Daily consumption & Average daily material consumption \\
\hline Place of consumption & Process / zone where material is consumed (e.g. cell 14) \\
\hline Place of storage & Address (location) where the material is stored \\
\hline Intensity of ordering & Frequency of order from the supplier \\
\hline Supplier & Name of the material supplier \\
\hline Supplier - city & The city where the supplier resides \\
\hline Supplier - region & Region where is supplier allocated \\
\hline Supplier- country & Supplier's country of origin \\
\hline Type of transport unit & Type of packaging (e.g. single, reversible) \\
\hline Weight of the transport unit & Weight of empty package \\
\hline The weight of one piece & The weight of one piece \\
\hline Weight of the whole package & Weight of full packing material \\
\hline The Length of the transport unit & Length or depth of pack \\
\hline The width of the transport unit & Packaging width \\
\hline The height of the transport unit & Packaging height \\
\hline Consumption for 1 product & The number of parts needed for 1 final product \\
\hline Hourly consumption & Maximum number of units used per hour \\
\hline Number of units per transport unit & Number of packages in one package \\
\hline The need for packaging per hour & The maximum number of packs needed per hour \\
\hline Transport dose & Standard delivery size in days (1 week = 5 days) \\
\hline Shipper & The company providing transportation services \\
\hline Delivery time & Transport time required for shipment from supplier to plant (in days) \\
\hline Number of cards in circulation & The number of tensile signals that are in the system \\
\hline Vendor rating & $\begin{array}{l}\text { Supplier performance evaluation that includes timeliness of delivery, } \\
\text { quality }\end{array}$ \\
\hline
\end{tabular}

A decisive condition for determining how data is integrated into a spreadsheet or database software is the amount of data the user wants to manage in this way. In case a large amount of data, the database software can be up to 60 times faster when searching for data as a spreadsheet editor. The amount of data affects the size of the production and the variation of the products produced.
In Table 2, creating a PFEP table merged and integrated data from 12 files, which can bring benefit in the form of shortening the time to search for information.

\section{Results}

In the case study, the measurement of all types of packaging in all partial warehouses was carried out in the company in order to quantify the amount of material 
DATA STRUCTURE OF INBOUND AND OUTBOUND MATERIAL FOR PLANNING AND LOGISTIC STREAMLINING IN COMPANIES

Peter Ignácz

required to store the material and the volume offered by the shelf available to centralize the material from the partial warehouse to the shelf. The measurement was focused on:

Length of packaging.

Width of packaging.

Height of packaging.

The data about the actual dimensions of the packaging for individual parts used in the production can subsequently be converted to cubic meters to calculate the volume required for the storage of all parts. The formula (1) used to calculate the volume is as follows:

$$
P V=L P \times W P \times H P
$$

$P V$ - Packaging volume $\left(\mathrm{m}^{3}\right)$

$L P$ - Length of packaging $(m)$,

$W P$ - Width of packaging $(m)$,

$H P$ - Height of packaging $(m)$.
All three dimensions of packaging for used parts are necessary due to the height of the packaging, it is necessary to dimension the shelves and the height of the individual traverses placed in the racks. The tables containing the volume calculations for each zone look like this:

The calculation of the required volume for the storage of parts and materials from the current state was set on cubic meters. This table represents the approximate required volume, because during the measurement, all the material has not had to be in the sub-zones, which means that the future storage place has to be dimensioned with a certain reserve of space, and the growing production must also be taken into account, which in the future will mean the increase in inventory and the areas where it will be necessary to store the material. Production can be understood as the conversion of inputs into another production process into tangible products or services [5].

Table 2 Calculating the amount of space required for the material

\begin{tabular}{|c|c|c|c|}
\hline \multicolumn{4}{|c|}{ CELL 1 TL } \\
\hline 1,2 & 0,8 & 1,12 & 1,0752 \\
\hline
\end{tabular}

\begin{tabular}{|c|c|c|c|c|}
\hline \multicolumn{3}{|c|}{ CELL 2} & SUM & Pieces \\
\hline 0,6 & 0,8 & 0,33 & 0,1584 & \\
\hline 0,4 & 0,6 & 0,16 & 0,0384 & \\
\hline 1,2 & 0,8 & 0,34 & 0,3264 & \\
\hline 1,2 & 0,8 & 0,34 & 0,3264 & \\
\hline 0,4 & 0,3 & 0,16 & $0,172 B$ & 9 \\
\hline 0,38 & 0,38 & 0,38 & 0,164616 & 3 \\
\hline 0,18 & 0,18 & 0,09 & 0,011664 & 4 \\
\hline 0,36 & 0,21 & 0,14 & 0,010584 & \\
\hline 0,86 & 0,66 & 0,76 & 0,431376 & \\
\hline 0,86 & 0,66 & 0,38 & $0,2156 B \mathrm{~B}$ & \\
\hline & & & 1,856328 & $\mathrm{~m} 3$ \\
\hline
\end{tabular}

\begin{tabular}{|c|c|c|c|c|}
\hline \multicolumn{3}{|c|}{ BT4 } & SUM & Pieces \\
\hline 0,4 & 0,3 & 0,16 & 0,1536 & $B$ \\
\hline 0,19 & 0,18 & 0,14 & 0,02394 & 5 \\
\hline 0,35 & 0,31 & 0,25 & 0,027125 & \\
\hline 0,31 & 0,5 & 0,25 & 0,03875 & \\
\hline 0,25 & 0,2 & 0,15 & 0,0075 & \\
\hline & & & 0,250915 & $\mathrm{~m} 3$ \\
\hline
\end{tabular}

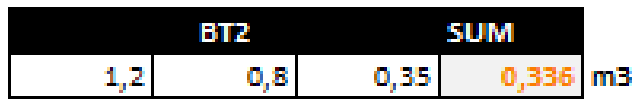

\begin{tabular}{|c|c|c|r|}
\hline \multicolumn{3}{|c|}{ CELL 3 TL } & SUM \\
\hline 1,2 & 0,8 & 0,75 & 0,72 \\
\hline 1,2 & 0,8 & 0,75 & 0,72 \\
\hline
\end{tabular}

\begin{tabular}{|c|c|c|c|c|}
\hline \multicolumn{2}{|c|}{ CELL 4 ASSY } & \multicolumn{2}{|r|}{ SUM } & \multirow{2}{*}{$\begin{array}{r}\text { Pieces } \\
12\end{array}$} \\
\hline 0,15 & 0,18 & 0,09 & 0,02916 & \\
\hline 0,15 & 0,18 & 0,09 & 0,00486 & 2 \\
\hline 0,15 & 0,18 & 0,09 & 0,02916 & 12 \\
\hline 0,23 & 0,24 & 0,16 & 0,017664 & 2 \\
\hline 0,22 & 0,23 & 0,16 & 0,008096 & \\
\hline 0,22 & 0,15 & 0,07 & 0,00231 & \\
\hline 0,4 & 0,3 & 0,16 & 0,1344 & 7 \\
\hline 0,5 & 0,31 & 0,25 & 0,89125 & 23 \\
\hline & & & 1,1169 & $\mathrm{~m} 3$ \\
\hline
\end{tabular}

\begin{tabular}{|c|c|c|c|c|}
\hline CELL7 & \multicolumn{5}{c|}{ SUM } & Pieces \\
\hline 0,6 & 0,4 & 0,16 & 0,6528 & 17 \\
\hline 0,3 & 0,4 & 0,16 & 0,096 & 5 \\
\hline 0,39 & 0,23 & 0,15 & 0,08073 & 6 \\
\hline 0,3 & 0,39 & 0,28 & 0,03276 & \\
\hline 0,38 & 0,3 & 0,3 & 0,0342 & \\
\hline 0,4 & 0,3 & 0,16 & 0,0576 & 3 \\
\hline 0,6 & 0,4 & 0,16 & 0,0768 & 2 \\
\cline { 4 - 5 } & & & 1,03089 & $\mathbf{m 3}$ \\
\cline { 4 - 5 }
\end{tabular}

\begin{tabular}{|l|l|l|}
\hline SUM & 7,1 & $\mathrm{~m} 3$ \\
\hline
\end{tabular}

$\sim 17 \sim$ 
In the next step, the volume of the rack no. 1 was counted in terms of multiplying the length, width and height of the rack in cubic meters, resulting in the total volume of the rack. To clarify the space available in Shelf No 1 , it is necessary to deduct the volume of traverses provided by the shelf and creating individual height levels therein.

Table 3 Calculation of available rack volume 2

\begin{tabular}{|c|c|c|r|}
\hline \multicolumn{4}{|c|}{ Regal 1 } \\
\hline 2,7 & 4,5 & 1,12 & 13,608 \\
\hline
\end{tabular}

\begin{tabular}{|c|c|c|c|c|}
\hline \multicolumn{2}{|c|}{ Traverza } & \multicolumn{2}{|c|}{ SUM } & Pieces \\
\hline 0,11 & 2,7 & 0,05 & 0,0891 & 6 \\
\hline
\end{tabular}

Regal 1 - Traverzy
\begin{tabular}{|c|c|c|c|}
\hline \multicolumn{3}{|c|}{13,5} & $\mathrm{~m} 3$ \\
\hline \multicolumn{3}{|c|}{ Regal 2 } & SUM \\
\hline 0,5 & 2,7 & 1,1 & 1,485 \\
\hline 0,5 & 2,7 & 1,1 & 1,485 \\
\hline 0,5 & 1,8 & 1,1 & 0,99 \\
\hline 0,5 & 1,8 & 1,1 & 0,99 \\
\hline
\end{tabular}

The volume of traversers was calculated in the same way as when calculating the rack volume, and the same formula for volume calculation was used. For the calculation of the final area, it is necessary to deduct the sum of the volume of all traverses in the shelves no. 1 . The calculation of the total usable area of the rack no. 1 is as follows:

$$
13.608 m^{3}-0.0891 m^{3}=13.5189 m^{3} \cong 13.5 m^{3}
$$

The same volume calculation was also used for rack no. 2 (Table 3 ). The volume calculation formula did not differ, with the difference that the method of design and use is planned only on one shelf, which means that it is not necessary to integrate deduction of traverse volume when calculating the total usable volume, as was the case for shelf no. 1 .

Volume of rack no. 2. $=4.95 \mathrm{~m}^{3}$

Sum of available volume in storage racks:

$$
13.5 m^{3}+4.95 m^{3}=18.45 m^{3} \cong 18.5 m^{3}
$$

Total volume area per warehouse: $\quad 18.5 \mathrm{~m}^{3}$ Approximate requested volume: $\quad 7.1 \mathrm{~m}^{3}$

\section{Conclusion}

The data structure in one table, respectively in table editor allows using the formulas to update all the necessary input and after transformation also output data about material for each company, whether the areas needed for storage for a particular material, a material consumption calculation that influences saturation and balance of logistics, or ABC and XYZ analysis. A PFEP table with this structure allows these data to be calculated and updated on a daily basis without the need to manage and browsing in other tables. Its added value is time saving and integrated data with secure update as well as flexibility. Correct information is necessary for correct decisions.

\section{References}

[1] FARAHANI, R., REZAPOUR, S., KARDAR, L.: Logistics Operations and Management: Concepts and Models, London, Elsevier Inc., 2011.

[2] VIESTOVÁ, K. et al.: Lexikón logistiky, $2^{\text {nd }}$ ed., Bratislava, Lura edition, 2007. (Original in Slovak)

[3] RUSHTON, A., CROUCHER, P., BAKER, P.: The Handbook of Logistics and Distribution Management, Kogan Page Limited, London, 2010.

[4] HARRIS, R., HARRIS, Ch., WILSON, E.: Tvoríme materiálové toky, Príručka o štíhlom zásobovaní pre profesionálov z výrobných odvetví, Žilina, IMI Print, s.r.o., 2008. (Original in Slovak)

[5] SYNEK, M., KISLINGEROVÁ, E. et al.: Podniková ekonomika, Praha, C.H. Beck, 2010. (Original in Slovak)

\section{Review process}

Single-blind peer reviewed process by two reviewers. 